\title{
FUNCTIONAL MORPHOMETRY OF ARISTEUS ANTENNATUS (RISSO, 1816) (DECAPODA, ARISTEIDAE)
}

\author{
BY \\ F. SARDA, C. BAS and J. LLEONART \\ Institut de Ciències del Mar (CSIC), Pg. Nacional s/n, E-08039 Barcelona, Spain
}

\begin{abstract}
Growth as reflected by measurements of different body parts of the pink shrimp, Aristeus antennalus (abdomen, scaphocerite, uropods, and segments on the third and fourth pereiopods) was related to carapace length by type-I regression analysis. There were differences in the relative growth of swimming appendages and pereiopods. For the former (abdomen, uropods, and scaphocerite) growth was negatively allometric at a statistically significant level, whereas for the latter (pcreiopod segments) growth either was isometric or cxhibited a slightly positive allometry. Comparison of the measurements between the sexes revealed differences in growth only for the uropods, with the slopes of the regression lines indicating higher negative allometry in females than in males. There was no cvidence of growth discontinuity for any body part over the life cycle of individuals of this species. The results have been compared to the findings reported by other investigators working with other specics of shrimps, prawns, lobsters, and crabs, and the relative growth of the different body parts has been related to the different life stratcgies of each group.
\end{abstract}

\section{RESUMEN}

Sc estudia el crecimiento relativo de varias medidas longitudinales del cucrpo de la gamba rosada, Aristeus antennatus (abdomen, cscafocerito, uropodos y artejos del tercer y cuarto periopodos), respecto a la longitud del caparazón, mediante un análisis de la regresión de tipo-I. Se observan diferencias en el crecimiento relativo de los apéndices natatorios y pereiopodos. En los primeros (abdomen, uropodos y escafocerito), el crecimiento fue significativo para una alometría negativa, mientras que para los scgundos (artejos de los pereiopodos), fuc isométrico o con alometría positiva débil. Comparativamente entre sexos, se observan diferencias significativas solo en el erecimiento de los uropodos, presentando las hembras una alometría negativa más fuerte que los machos. No se observó evidencia de discontinuidad, en ningún apéndice, a lo largo del crecimiento de esta especic. Los resultados obtenidos se han comparado con los registrados por otros autores en otras especies de gambas, langostas y cangrejos, de manera que la discusión se plantea relacionando el crecimiento relativo de estas especies con las diferentes estrategias vitales de cada grupo.

\section{INTRODUGTION}

Relative growth has been widely studied in crustaceans, and both conceptual and empirical aspects have been discussed by various investigators, e.g., Hartnoll (1974, 1978), Finney \& Abele (1981), Huber (1985), and Blackstone (1986). The relative growth rates (chiefly linear measurements) of different body parts and function of body parts, sexual dimorphism, sexual maturity, changes in individual behaviour with puberty, fecundity, and changes in the weight-length relationship are just a few of the processes that may be studied through 
morphometric analysis and analyses of growth in general, and there is an extensive literature dealing with such aspects (Hartnoll, 1985).

The allometry of certain body parts can be of singular importance, especially among brachyurans, and may be a diagnostic character for some species. A number of investigators have studied this group and have established that sexual maturity is represented by the points of intersection between the segments of the regression line for specific variables (Du Preez \& McLachlan, 1984; Gaertner \& Laloé, 1986; Davidson \& Marsden, 1987; Clayton, 1990; Abelló et al,, 1990, being some of the more recent publications). Growth processes have also been studied in certain species of clawed and spiny lobsters, primarily in respect of abdominal width or morphological differentiation of chelae at puberty, a frequent indicator of sexual dimorphism; for general reviews see Aiken \& Waddy (1980) for Homarus americanus H. Milne Edwards, 1837 and Sardà (in press) for Nephrops norvegicus (L., 1758).

In contrast, studies on growth of this type are less common in the case of shrimps and prawns, possibly because proportions of body parts of such species, unlike those of the large chelae of other decapods, do not undergo appreciable variations during growth. Additionally, many of these species are fast-growing, and the females in some species do not carry the eggs during incubation, thus lessening morphometric differences between body measurements during an individual's lifetime. This has been borne out for the morphometry of Heterocarpus reedi Bahamonde, 1955 (cf. Arana, 1970) and for the weight-length relationships of Aristeus antennatus (Risso, 1816) (cf. Bas, 1966; Balestra et al., 1975; Demestre, 1990) and for Penaeus kerathurus (Forskål, 1775) (cf. San Feliu, 1966; Rodríguez, 1987), as well as for other penaeids (Costello \& Allen, 1965; Rao, 1967; Garcia-Pinto, 1970; Le Reste et al., 1974; D’Incão \& De Calasans, 1978, Menz \& Bowers, 1980; Kirkwood \& Somers, 1984; Huber, 1985). Nevertheless, the literature contains few comprehensive morphometric studies on natantian crustacean species, probably because such species are mainly of interest for aquaculture, in which the weight-length relationship takes on primary importance.

The object of the present study was Aristeus antennatus (Risso, 1816), a species found in the Mediterranean, neighbouring regions of the Atlantic Ocean, and south-eastern African coasts, and of great interest in terms of both ecology and fisheries. A number of workers have investigated the basic biology and fisheries of this species in the region (Massuti, 1961; Bas, 1966; Arrobas \& RibeiroCascalho, 1987; Relini \& Orsi Relini, 1987; Sardà \& Demestre, 1987, 1989; Tobar \& Sardà, 1987, 1992; Demestre, 1990; Demestre \& Lleonart, 1993). The present study undertook to analyze thirteen different linear measurements with a view to establishing relative growth, examining both pre- and post-pubertal differences between the sexes, and ascertaining the variability in certain measurements. 


\section{MATERIALS EN METHODS}

Specimens of both sexes of $A$. antennatus were obtained directly from commercial fishing vessels operating out of Barcelona harbour, which fish the middle slope at a mean depth from 500 to $700 \mathrm{~m}$, the normal distribution range for this shrimp species.

A total of thirteen linear measurements of different body parts were made on specimens of $A$. antennatus of both sexes (fig. 1). The measurements were defined as follows:

Carapace length $(\mathrm{CL})$ : from the posterior margin of the orbit to the posterior margin of the carapace, parallel to the axis of the body.

Abdominal length (AL): laterodorsally from the anterior margin of the first abdominal segment to the posterior margin of the last abdominal segment.

Uropodal endopodite and exopodite length (U. endo, U. exo.): from the margin of the commissure of the articulation to the end of the terminal spinc on the dorsal ridge.

Scaphocerite length (S): from the margin of the commissurc of the articulation to the end of the spine on the inner ridge.

Article length: The length of the ischium $(\mathbf{I})$, merus $(\mathbf{M})$, carpus $(\mathrm{C})$, and propodus $(\mathrm{P})$ on the third and fourth pereiopods, measured as the distance between articulations.

Other linear measurements, e.g., rostral length, have not been considered, because they were analyzed previously by Sardà \& Demestre (1989). Two adjacent pereiopods were chosen, the third pereiopod because the propodus bears a chela (pincer) and it is the longest of the chela-bearing pereiopods, and the fourth pereiopod, which presents no chela, but the propodus carries a simple dactylus distally, and is also the longest pereiopod. The assumption was that morphological variability might be greatest in these two pereiopods on account of their greater lengths. In addition to this set of measurements, measurements for each of the abdominal segments were reported previously by Balestra et al. (1975).

All these measurements were related to carapace length, which in all cases was taken to be the independent variable. A power equation of the form $y=$ a. $x^{b} \cdot e^{\varepsilon}$ (Huxley, 1924, 1932; Thompson, 1942) was used, where $x$ was the independent variable and $y$ was the dependent variable, representing the measurements of body parts; $a$ and $b$ were constants; $e$ was the base of the natural system of logarithms; and $\varepsilon$ was a normally distributed random variable, such that $\mathrm{e}^{\varepsilon}$ was a lognormally distributed random variable with a mean value of unity.

Linear regressions were calculated using the logarithmic transformation in order to smooth the variance:

$$
\ln (y)=\ln (\mathrm{a})+\mathrm{b} \ln (x)+\varepsilon
$$

The type of error in the model conditions the fitting procedure employed, which in this case was predictive regression (Ricker, 1973), also known as type-I regression (Sokal \& Rohlf, 1979). This method is appropriate for analyzing the relative growth between two measurements, an independent variable devoid of 


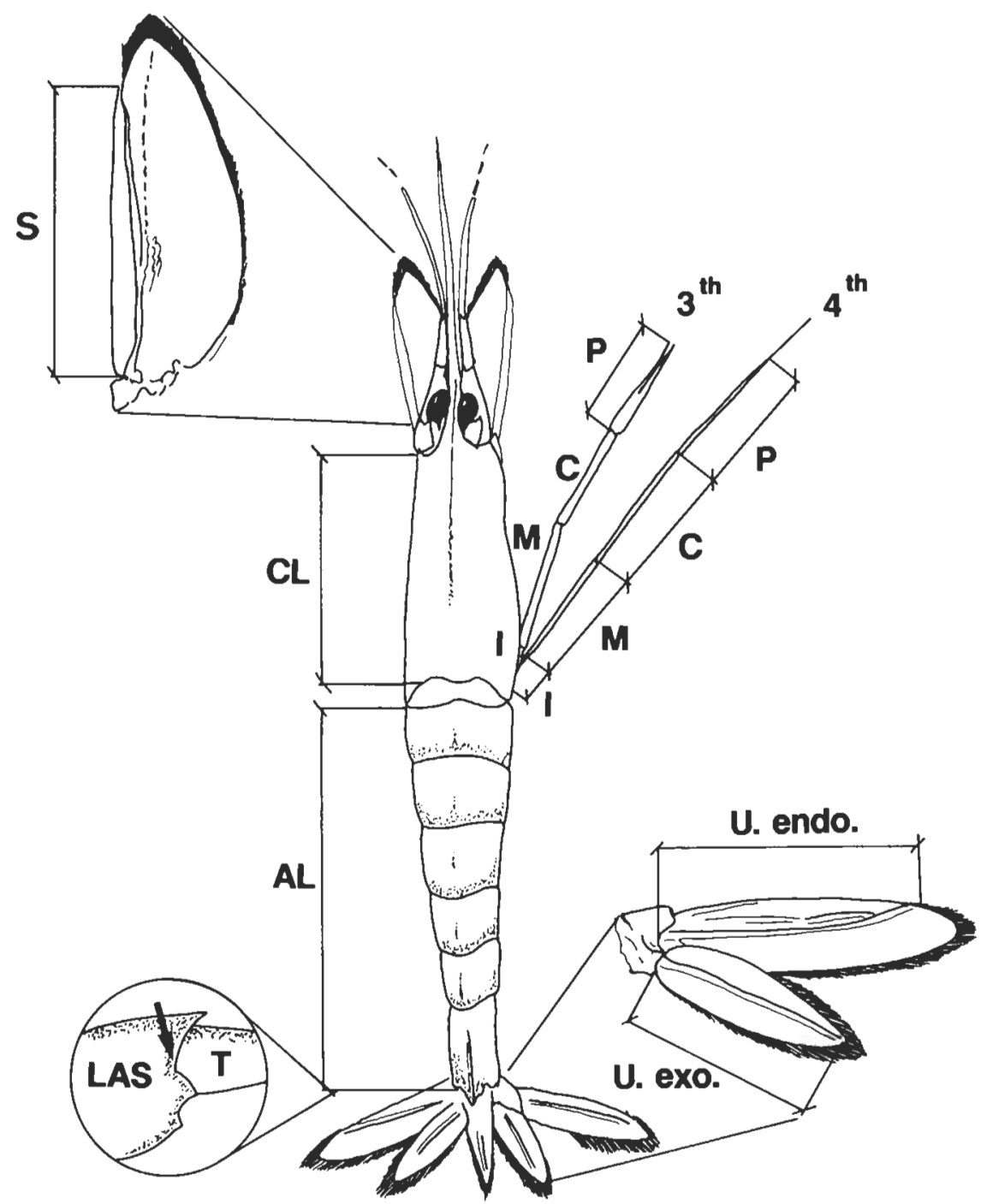

Fig. 1. Morphometric measurements taken: CL: carapace length; AL: abdominal length; LAS: last addominal segment; $\mathrm{T}$ : telson; U. exo.: uropodal exopodite; $U$. endo.: uropodal endopodite; I: ischium; M: merus; C: carpus; P: propodus; S: scaphoccrite.

both observation and process error, and a dependent variable subject to process error as described in (1). In contrast, when the error term affects both variables, in other words, when neither of the variables is error-free and hence the same treatment is applicable to each of the variables, as in the case of multivariate analysis, functional or type-II regression should be used as the fitting procedure. Thorough considerations of these aspects specifically for crustaceans 
can be found in Hartnoll (1978), Lovett \& Felder (1989) and Somerton (1980).

A test of statistical significance was then applied to the results to test for the hypothesis that growth was isometric $(b=1)$ and to compare the allometric growth indices for the two sexes (Sokal \& Rohlf, 1979).

\section{RESULTS}

Table I presents the parameters for the equations representing the relative growth of each variable in relation to carapace length, together with the value of the regression coefficient and the level of statistical significance for allometry, and a comparison of the slopes of the regression lines for the different variables by sex.

The table shows two overall trends in the relative growth patterns. One group (abdomen, uropods, and scaphocerite) was highly negatively allometric $(p<0.001)$, and the other group (pereiopod segments, excluding the carpus and propodus) was either isometric or positively allometric, though at a lower level of statistical significance $(p<0.05$ or $p<0.01)$. Pereiopod growth, particularly that of the first two segments, the ischium and the merus, on the third pereiopod, tended to be isometric; the statistical significance of linear growth of the merus in females was very weak $(p<0.05)$. On the whole, growth of the carpus and propodus was positively allometric $(p<0.001)$, more markedly so in females. Fig. 2 graphically represents the main relationships established.

The growth pattern for the fourth pereiopod differed between the sexes. In males, growth of both the carpus and merus was positively allometric, whereas

\section{Table I}

Values of relative growth parameters and level of statistical significance for each measurement variable. CL: carapace length; a: $y$-intercept; b; slope; $r$ : correlation coefficient; t: Student's t-test statistic; s: level of statistical significance (***: $p<0.001 ; * *$ : $0.01>0.001 ; *: p>0.01$; without mark: no significance); d.f.: degrees of freedom

\begin{tabular}{|c|c|c|c|c|c|c|c|c|c|c|c|c|c|c|c|}
\hline \multirow[b]{2}{*}{ Measures/CL } & \multicolumn{6}{|c|}{ Males } & \multicolumn{6}{|c|}{ Females } & \multicolumn{3}{|c|}{ Comparison } \\
\hline & $\mathrm{a}$ & $\mathrm{b}$ & $r$ & 1 & s & $\mathrm{d} \boldsymbol{f}$ & a & $b$ & $r$ & $\mathrm{t}$ & s & $\mathrm{d} f$ & 1 & s & $d f$ \\
\hline Abdomen & 3.632 & 0.774 & 0.981 & 15.82 & $* * *$ & 115 & 3.254 & 0.780 & 0.950 & 12.67 & \#*** & 185 & 0.36 & & 300 \\
\hline Uropod endop. & 0.667 & 0.904 & 0.948 & 3.38 & $* * *$ & 114 & 0.904 & 0.797 & 0.977 & 15.85 & **** & 182 & 3.46 & $* * *$ & 296 \\
\hline Uropod exop. & 0.885 & 0.868 & 0.968 & 6.27 & *** & 114 & 1.115 & 0.800 & 0.989 & 22.86 & **** & 185 & $3.0 !$ & ** & 300 \\
\hline Scaphocerite & 0.992 & 0.856 & 0.969 & 7.12 & $* * *$ & 114 & 1.002 & 0.840 & 0.990 & 18.94 & 茟 & 184 & 0.78 & & 299 \\
\hline Ischium 3rd & 0.131 & 1.112 & 0.901 & 0.81 & & 102 & 0.183 & 1.006 & 0.965 & 0.30 & & 160 & 0.75 & & 262 \\
\hline Merus & 0.479 & 1.008 & 0.957 & 0.26 & & 103 & 0.515 & 0.978 & 0.988 & 1.81 & $*$ & 160 & 0.92 & & 263 \\
\hline Carpus 3rd & 0.310 & 1.143 & 0.953 & 4.01 & $* * *$ & 103 & 0.300 & 1.155 & 0.982 & 8.93 & **** & 160 & 0.29 & & 263 \\
\hline Propodus 3rd & 0.359 & 1.079 & 0.924 & 1.80 & $*$ & 103 & 0.386 & 1.056 & 0.985 & 3.83 & **** & 160 & 0.50 & & 263 \\
\hline Ischium 4 th & 0.158 & 1.063 & 0.900 & 1.19 & & 93 & 0.166 & 1.037 & 0.933 & 1.15 & & 151 & 0.45 & & 241 \\
\hline Merus & 0.844 & 0.892 & 0.934 & 2.94 & ** & 93 & 0.568 & 0.992 & 0.988 & 0.14 & & 151 & 2.66 & $* *$ & $24 !$ \\
\hline Carpus 4 th & $0.43 \mathrm{I}$ & 1.123 & 0.943 & 2.84 & $* *$ & 92 & 0.534 & 1.009 & 0.980 & 0.56 & & 150 & 2.72 & ** & 232 \\
\hline Propodus 4th & 0.280 & 1.101 & 0.885 & 1.54 & & 78 & 0.439 & 0.933 & 0.968 & 3.39 & ** & 150 & 1.91 & $*$ & 221 \\
\hline
\end{tabular}



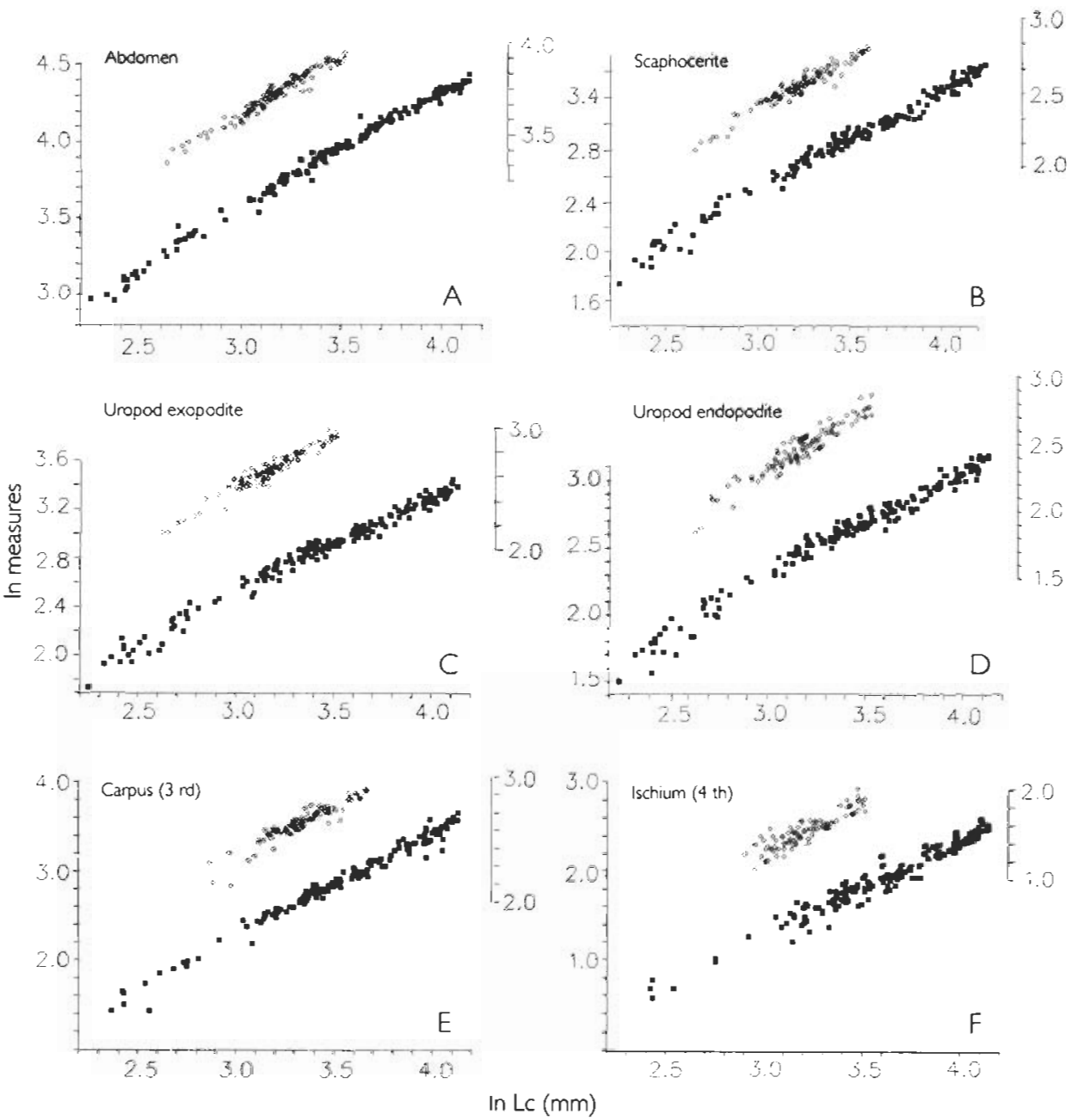

Fig. 2. Logarithmic plot of the relative growth of measurements for the different body parts against carapace length for both sexes (in $\mathrm{mm}$ ); black squares: females (left-hand scale); white squares: males (right-hand scale); $\mathrm{Lc}=\mathrm{CL}=$ carapace length.

in females growth was positively allometric only for the propodus, at a moderate level of statistical significance $(p<0.01)$. Comparison of the other measurements between the sexes yielded differences only for the uropods (table I), and the slopes were indicative of more negatively allometric growth in females than in males. Growth of all the segments of the third pereiopod was the same in both sexes.

Growth discontinuities are to be expected around the size of sexual maturity: CL $27 \mathrm{~mm}$ for females and CL $24 \mathrm{~mm}$ for males (Sardà \& Demestre, 1987). None of the relationships, shown in fig. 2, provided any clear and general 
indication of significant discontinuities in the relative growth. For that reason it was not considered worthwhile to pursue that line of investigations further.

\section{DISCUSSION}

The measurements taken can be classed in three subdivisions, related to distinct functional aspects:

1. Body: carapace and abdominal length, directly related to overall metabolic processes, primarily reproduction (development of gonads in the cephalothorax) and rapid locomotion (muscle mass of the abdomen for swimming).

2. Swimming appendages: represented by scaphocerite and uropodal length, both closely related to swimming ability, balance, and direction of movement. The generally paddle-like shape of these appendages, and the dorsal ridge ending in a spine that they bear, serve to strengthen them structurally, affording them both robustness and functional characteristics appropriate for use as an "oar" or "rudder".

3. Pereiopods (legs): directly related to walking ability and cropping behaviour in feeding when rooting for food in the substrate. Development of these extremities is indicative of adaptation to the demersal habitat.

On analyzing the comparative morphology of these structures, one aspect stands out clearly from the results of the present study: differences in the relative growth of the swimming appendages and the pereiopods. The swimming appendages (abdomen, uropods, and scaphocerite) were negatively allometric at a high level of statistical significance. This obviously results in a reduction in overall swimming ability with size. The segments of the pereiopods were positively allometric or isometric, making total allometry for the member as a whole positive. Since the relationship between size and weight has been commonly reported to increase following a power series (Bas, 1966; Le Reste et al., 1978; D'Incão, 1978; Ivanov \& Krylov, 1980; Menz \& Bowers, 1980; Rodríguez, 1987; Demestre, 1990), and the ability for rapid locomotion decreases with size, it is to a certain extent reasonable to expect the walking legs to become longer as overall size increases.

These findings have been corroborated by research on feeding in this species reported by Cartes \& Sardà (1989), which showed that the share in the diet of in faunal prey items, which live deeper in the substrate, rose in larger individuals. Further confirmation of this hypothesis, i.e., that larger individuals dwell in closer contact with the bottom, is provided by the fact that the highest positive allometry was recorded for dactylus length on the third pereiopod, particularly in females, where it attains a larger size than in males (Sardà \& Demestre, 1987). Presumably this pereiopod is used in this species' cropper feeding strategy. Cartes et al. (1993) also reported that larger Pasiphaea multidentata Esmark, 1866, adults were less able to migrate to the bathypelagic zone. Unfortunately, there are no studies on members of the Penaeoidea other than Aristeus antennatus with which to compare relative pereiopod growth. Catches in 
the demersal trawl fishery consist chiefly of medium and large individuals, which constitutes further evidence pointing to the higher dependence of larger individuals on the substrate (Tobar \& Sardà, 1987; Demestre, 1990).

The differences in uropod growth recorded between the sexes are also consistent with sexual dimorphism in this species in line with the hypothesis proposed, inasmuch as the maximum size of males is only about half that of females (Sardà \& Demestre, 1987). Accordingly, the swimming ability of males can be expected to be better than that of females. Even given isometry, larger specimens will in any case become less suited to a pelagic life because of the length/weight relationship, so, the negative allometry is additional to this.

Growth of the fourth pereiopod presented other statistically significant basic differences between the sexes; however, the level of statistical significance of these differences was lower $(p<0.01$ and $p<0.05)$.

Our findings for $A$. antennatus furnish no evidence of discontinuities during growth that would result in sudden changes in morphology at different stages in the life cycle. This agrees with the results of Bas (1966; total length/weight), Balestra et al. (1975; carapace length/abdominal somites length), and Demestre (1990; carapace length/weight), who also failed to find any discontinuities in the relationships between the measurements of other body parts in this same species. Similarly, no clear evidence of discontinuities in the relative growth of the main body parts has been gathered for other penaeid and aristeid species, and growth trends have in general been reported to be isometric (Arana, 1970; Le Reste et al., 1974; D’Incão \& De Calasans, 1978; Lobão \& Lona, 1979; Menz \& Bowers, 1980; Kirkwood \& Somers, 1984; Lobão et al., 1986; Rodríguez, 1987). This finding should be underscored, because it is one of the major differences with respect to other groups of crustaceans such as lobsters and crabs, in which changes in the relative growth of certain body parts (chiefly abdominal width, pereiopod length, or pincer shape) are quite marked and significant (e.g., Aiken \& Waddy, 1980; Finney \& Abele, 1981; Hartnoll, 1985; Gaertner \& Laloé, 1986; Abelló et al., 1990; Clayton, 1990). The underlying cause of the discontinuities in reptantian species can probably be attributed to the slower growth rates (reflected by annual values of the parameter $k$ in the Von Bertalanffy equation or from 0.05 to 0.6 ) for these species (Campbell, 1983, for Homarus americanus; Abelló, 1986, for Liocarcinus depurator (L., 1758); González-Gurriarán, 1985, for Macropipus puber (L., 1767); Marín, 1985, for Palinurus elephas (Fabr., 1787); Dall et al., 1990, for various species; Sardà, 1985, for Nephrops norvegicus (L., 1758)) as compared to the growth rates of Natantia, with annual values of $k$ between 0.2 and 2.0; Menz \& Blake, 1980 and Dall et al., 1990, for various shrimp and prawn species; Skuladottir, 1981, and Nilssen \& Hopkins, 1991 for Pandalus borealis Krøyer, 1838; Kirkwood \& Somers, 1984, for Penaeus esculentus Haswell, 1879, and Penaeus semisulcatus De Haan, 1844; García, 1985, for various penaeids; Arrobas \& Ribeiro-Cascalho, 1987, for Parapenaeus longirostris (Lucas, 1846); Demestre, 1990, for Aristeus 
antennatus), in view of the influence of metabolic patterns on the life strategy of organisms. Sardà et al. (1989) found the degree of calcification of the exoskeleton to be a major factor affecting the growth rates of different crustacean groups and established associations between crustacean groups and their life histories on the basis of the $r$ and $K$ strategies. Mating and the associated sexual behaviour, territorial behaviour and aggression, horizontal distribution across the substrate, females carrying eggs during incubation (relative increase in abdominal width) (Aiken \& Waddy, 1980) are some of the primary functions responsible for the development of morphometric changes during the life cycle of highly calcified crustaceans like lobsters and crabs. However, these arguments must be considered carefully because the numerous exceptions observed overall on crab species (Brachyura).

Obviously, the weaker calcification of the carapace of natantian decapod crustaceans endows them with greater swimming and locomotive ability. It is also responsible for overlap between growth and reproduction (Webster, 1982; Anderson et al., 1985; Sardà, 1991), such that both these processes occur continuously, with no breaks in relative growth.

\section{ACKNOWLEDGEMENTS}

The present study was funded by the Institut d'Estudis Catalans (Barcelona) during 1992. The authors wish to express their appreciation to Dr. I. Palomera for her aid in implementing the appropriate computer system and to Ms. G. Fuster and Mr. J. M. Anguita for their technical assistance. Mr. R. Sacks prepared the English translation.

\section{LITERATURE CITED}

ABelló, P., 1986. Anàlisi de les poblacions de crustàcis decàpodes demersals al litoral Català: aspectes biológics del braquiur Liocarcinus depurator: 1-185. (Tesis Doctoral, Universitat de Barcclona).

Arelló, P., J. P. Pertierra \& D. G. Reid, 1990. Sexual size dimorphism, relative growth and handedness in Liocarcinus depurator and Macropipus tuberculatus (Brachyura: Portunidac). Scient. Mar., 54 (2): 195-202.

Aiken, D. E. \& S. L. Waddy, 1980. Reproductive biology. In: J. S. CobB \& B. F. Phillips (cds.), The biology and management of lobsters, 1: 215-276. (Academic Press, London).

Anderson, S. L., W. H. Clark \& E. S. Chano, 1985. Multiple spawning and molt synchrony in a free spawning shrimp (Sicyonia ingentis, Penacoidca). Biol. Bull., Woods Hole, 168: 377-394.

Arana, P., 1970. Crecimiento relativo del camarón nylon, Helerocarpus reedi, de la costa de Valparaíso. Invs. Marinas, 1 (6): 111-138.

Arrobas, I. \& A. Ribeiro-Cascalmo, 1987. On the biology and fishery of Aristeus antennalus (Risso, 1816) in the South Portuguese coast. Inv. Pesq., Barcelona, 51 (suppl. 1): 233-244.

Balestra, V., M. Bianchini \& R. Cattaneo, 1975. Studio ed osservazioni biometrico-statistiche sull'accrescimiento relativo di alcuni crostacei batiali. Atti dell'Academia Ligure di Science e Lettere, 32: 3-39.

BAs, C., 1966. La gamba rosada (Aristeus antennalus). Publicaciones Técnicas de la Junta de Estudios de Pesca, 5: 143-155.

Blackstone, N. W., 1986. Relative and specific growth rates in Crustaceans. Growth, 50 (1): $118-127$.

CampBell, A., 1983. Growth of tagged American lobsters, Homarus americanus, in the Bay of Fundy. Canadian Journ. Fisher. aquat. Sci., 40 (10): 1667-1675. 
Cartes, J. E. \& F. SARDA, 1989. Feeding ecology of the decpwater aristeid crustacean Aristeus anlennalus. Mar. Ecol. Prog. Scr, 54: 229-238.

Cartes, J. E., F. Sardà, J. B. Company \& J. Lleonart, 1993. Day-light migrations by deep-sea decapod crustaceans in experimental samplings in the Western Mediteranean. Journ. exp. mar. Biol. Ecol., 171: 63-73.

Clayton, D. A., 1990. Crustacean allomctric growth: a case for caution. Crustaceana, 58 (3): 270-290.

Costello, T. J. \& D. M. Allen, 1965. Synopsis of biological data on the pink shrimp Penaeus duorarum duoraum. FAO Fish. Synops., 103: 1499-1537.

Dall, W., B. J. Hill, P. C. Rothlisberg \& D. J. Staples, 1990. The biology of the Penaejdae. Advances in Marine Biology, 27: i-xiii, 1-489. (Academic Press, London).

Davidson, R.J. \& I. D. Marsden, 1987. Size relationship and relative growth of the New Zealand swimming crab Ovalipes calharus (White, 1843). Journ. Crust. Biol., 7 (2): 308-317.

Demestre, M., 1990. Biologia persquera de la gamba Aristeus antennatus (Risso, I816) en el mar catalán. Universidad de Barcelona, $443 \mathrm{pp}$.

Demestre, M. \& J. Lleonart, 1993. The population dynamics of Aristeus antennalus (Decapoda: Dendrobranchiata) in the Northwestern Mediterranean. Sci. Mar., 57 (2-3): 183-189.

Du Preez, H. H. \& A. Mclachlan, 1984. Biology of the threc-spot swimming crab, Ovalipes punclatus (De Haan), I. Morphometrics and relative growth (Decapoda, Portunidae). Crustaceana, $\mathbf{4 7}(1):$ 72-82.

D'Incão, F, 1978. Curva de crecimento del "Camarão rosa" Penaeus paulensis Pérez-Farfante, 1967 na lagõa dos Patos. Atlantica, Base Oceanografica, Universidad de Rio Grande, Brasil, 3: $57-65$.

D’Incão, F. \& D. K. De Calasans, 1978. Relaçoes biometricos do "Camarão rosa" Penaeus paulensis Pérez-Farfante, 1967 na lagõa dos Patos. Atlantica, Base Occanografica, Universidad de Rio Grande, Brasil, 3: 75-78.

FinNey, W. C. \& L. G. AbeLE, 1981. Allometric variation and sexual maturity in the obligate coral commensal Trapezia ferruginea Latreille (Decapoda, Xanthidae). Crustaceana, 41 (2): $114-129$.

Gaertiner, D. \& F. Laló, 1986. Étude biométrique de la taille à premiére maturité sexuclle de Geryon marilae Manning et Holthuis, 1981 du Sénégal. Occanol. Acta, 9 (4): 479-487.

GarcIA, S., 1985. Reproduction, stock assessment models and population parametcrs in exploited penaeid shrimp populations. In: P. C. Rothlrsberg et al. (eds.), Second Australian National Prawn Seminar: 139-158. (Cleveland, Australia).

Garcia-Pinto, L., 1970. Estudio morfométrico del Camarón blanco Penaeus schmilli. Boletin del Centro de Investigaciones Biológicas de Venezuela, 4: 1-35.

Gonzales-Gurriarán, E., 1985. Crecimiento de la nécora Macropipus puber (L.) (Decapoda, Braquiura) en la Ria de Arousa (Galicia, NW España), y primeros datos sobrc dinámica de la población. Bol. Inst. Espagnol Oceanogr., 2 (1): 33-151.

Hartioll, R. G., 1974. Variation in growth pattern between some secondary sexual characters in crabs. Crustaceana, 27: 131-136.

- - 1978. The detcrmination of relative growth in Crustacea. Crustaceana, 34 (3): 282-293.

- -, 1985. Growth, sexual maturity and reproductive output. In: A. M. WenNer (ed.), Factors in adult growth. Crustacean Issues, 3: 101-128. (A. A. Balkema, Rotterdam \& Boston).

Huber, M. E., 1985. Allometric growth of the carapace in Trapezia (Brachyura, Xanthidae).Journ. Crustacean Biology, 5 (1): 79-83.

Huxley, J. S., 1924. Constant differential growth-ratios and their significance. Nature, London, 114: 895.

- - 1932. Problems of relative growth: i-xix, 1-276. (Methuen, London).

Ivanov, B. G. \& V. V. KRYLov, 1980. Length-weight relationships in some common prawns and lobsters (Macrura, Natantia and Reptantia) from the western Indian Ocean. Crustaceana, 38 (3): 279-289.

Kirkwood, G. P. \& F. Somers, 1984. Growth of two species of Tiger Prawn, Penaeus esculenlus and P. semisulcalus, in the Western Gulf of Carpentaria. Australian Journ. Mar. Freshw. Res., 35: 703-712.

Le Reste, L., J. Marcille \& F. Barbe, 1974. Biométrie de quelques crevettes pénéides à Madagascar. ORSTOM, Doc. Sci. Mission Nosy-Bé, 46: 1-29.

LoвÃo, V. L. \& F. B. LonA, 1979. Biometria e isometria en Macrobrachium hollhuisi Genofre \& Lobão, 1976 (Crustacea, Decapoda). Boletim Inst. Pesca. São Paulo, 6: 17-50. 
Lobão, V. L., W. C. Valente \& J. T. C. Mello, 1986. Crecimiento relativo de Macrobrachium carcinus L. (Decapoda, Palacmonidae). Boletim Inst. Pesca São Paulo, 3 (1): 105-109.

LovetT, D. L. \& D. L. Felder, 1989. Application of regression tcchniqucs to studies on relative growth in crustaceans. Journ. Crust. Biol., 9 (4): 529-539.

Marin, J., 1985. Etude de la croissance des crustáces à partir des données de marquages recapturcs. Application à la langoustc de Corse, Palinurus elephas Fabricius. ICES. CM 1985/ $\mathrm{K}: 26,17 \mathrm{pp}$

Massu'tr, M., 1961. Premic̀res observations bionomiques et biologiques sur la crevette rose Aristeus antennatus (Risso) aux fonds des Iles Baléares. Rapp. Proc. - verb. CIESM, 16 (2): $551-557$.

Menz, A. \& B. F. Blake, 1980. Experiments on the growth of Penaeus vannamei Boone. Journ. cxp. mar. Biol. Ecol, 48: 99-112.

Menz, A. \& A. B. Bowers, 1980. Bionomics of Penaeus vannamei Boone and Penaeus stylirostris Stimpson in a lagoon on the Mexican Pacific coast. Est. coastal mar. Sci., 10: 685-697.

Nilssen, E. M. \& C. C. E. Hopkins, 1991. Population parameters and life histories of the decpwater prawn Pandalus borealis from different regions. International Council for the Exploration of the Sea, ICES CM 1991/K:2: 1-27.

RAO, A. V. P., 1967. Some observations on the biology of Penaeus indicus H. M. Edwards and Penaeus monodon Fabricius from the Chilka Lake. Indian Journ. Fisher, 14 (1-2): 251-270.

Relini, G. \& L. Orsi Relini, 1987. The declinc of red shrimp stocks in the gulf of Genoa. Inv. Pesq., Barcelona, 51 (suppl. 1): 245-260.

RickeR, W. E., 1973. Linear regression in fishery research. Journ. Fish. Res. Board Canada, 30 (3): 409-434.

Rodríguez, A., 1987. Biologia del langostino Penaeus kerathurus (Forskål, 1775) del Golfo de Cádiz. III Biometría, edad y crecimiento. Inv. Pesq. Barcclona, 51 (1): 23-37.

SAN Feliu, J. M, 1966. Observaciones sobre la muda y el crecimicnto del lagostino Penaeus kerathurus (Forskål, 1775) en acuario. Inv. Pesq. Barcelona, 30: 685-705.

SARDȦ, F., 1985. Estudio de la edad, crecimiento y frecucncia de muda, en cautividad, de Nephrops norvegicus L. del mar Catalán. Inv. Pesq. Barcelona, 49 (2): 139-154.

- -, 1991. Reproduction and moult synchronism in Nephrops norvegicus (L.) (Decapoda, Nephropidac) in the Western Mediterranean: is spawning annual or biennial?. Crustaccana, 60 (2): 185-199.

- - (in press). A review (1967-1990) of some aspects of the life history of Nephrops nonvegicus. ICES mar. Sci. Symposia, 199.

SARdì, F., M. L. Cros \& B. SesE, 1989. Ca balance during moulting in the prawn Aristeus antennatus (Risso, 1816): the role of cuticle calcification in the life cycle of decapod crustaceans. Journ. exp. mar. Biol. Ecol., 129: 161-171.

SARdì, F. \& M. Demestre, 1987. Estudio biológico de la gamba Aristeus antennalus (Risso, 1816) en el Mar Catalán (NE de España). Inv. Pesq. Barcelona, 51 (1): 213-232.

- - \& - , 1989. Shortening of the rostrum and rostral variability in Aristeus antennalus (Risso, 1816) (Decapoda: Aristeidac). Journ. Crust. Biol., 9 (4): 570-577.

SkvladotTir, U., 1981. The deviation method. A simple method for detecting year-classes of a population of Pandalus borealis from length distributions. Proccedings of the international pandalid shrimp symposium. Grant Rep., 81 (3): 283-306.

Sokal, R. R. \& F. J. Rohlf, 1979. Biometria: 1-832. (H. Blume Ediciones, Madrid).

Somer'ron, D. A., 1980. A computer technique for estimating the size of sexual maturity in crabs. Canadian Journ. Fisher. Aquat. Sci, 37: 1488-1494.

Thompson, D. W., 1942. On growth and form: 1-1116. (Cambridge Univ. Press, Cambridge).

Tobar, R. \& F. SARdÀ, 1987. Análisis de la evolución de las capturas de gamba rosada, Arisleus antennatus (Risso, 1816), en los últimos decenios en Cataluña. Informes Técnicos del Instituto de Ciencias del Mar de Barcelona, 142: 1-20.

- - 1992. Annual and diel light cycle as a predictive factor in deep-water fisheries for the prawn Aristeus antemnatus (Risso, 1816). Fisheries Rescarch, 15: 169-179.

WEBSTER, S. G., 1982. Seasonal anecdysis and moulting synchrony in field populations of Palaemon elegans (Rathke). Estuarine, Coastal and Shelf Science, 15: 85-94. 